\title{
Tulane
}

Tulane Economics Working Paper Series

\section{Declining Wages for College-Educated Workers in Mexico: Are Younger or Older Cohorts Hurt the Most?}

\author{
Raymundo M. Campos-Vazquez \\ Centro de Estudios Economicos \\ El Colegio de Mexico \\ rmcampos@colmex.mx
}

\author{
Luis F. Lopez-Calva \\ Development Economics Vice Presidency \\ World Bank \\ lflopezcalva@worldbank.org
}

\author{
Nora Lustig \\ Department of Economics \\ Tulane University \\ nlustig@tulane.edu
}

Working Paper 1522

November 2015

\begin{abstract}
Wage inequality has declined in Mexico since 2000. Using data from Mexican labor surveys for the period between 2000 and 2014, we investigate if the decline was driven by wages declining more sharply for younger or older workers. We find that wages of older workers declined and the decline was more pronounced in the older the cohort. This would seem to support the hypothesis that older workers' skills have become obsolete.
\end{abstract}

Keywords: education, college, cohort, inequality, Mexico

JEL codes: I24, I25, J20, J31, O54 


\title{
Declining Wages for College-Educated Workers in Mexico: Are Younger or Older Cohorts Hurt the Most?1
}

\author{
Raymundo M. Campos-Vazquez* \\ Luis F. Lopez-Calva \\ Nora Lustig^
}

This Version: November 14, 2015

\begin{abstract}
Wage inequality has declined in Mexico since 2000. Using data from Mexican labor surveys for the period between 2000 and 2014, we investigate if the decline was driven by wages declining more sharply for younger or older workers. We find that wages of older workers declined and the decline was more pronounced in the older the cohort. This would seem to support the hypothesis that older workers' skills have become obsolete.
\end{abstract}

Keywords: Education; College; Cohort; Inequality; Mexico.

JEL: I24; I25; J20; J31; O54.

${ }^{1}$ The authors are grateful to Alma Santillan for her excellent research assistantship.

* El Colegio de Mexico, Camino al Ajusco 20, Col. Pedregal de Santa Teresa, 10740, Mexico DF, Phone: +52-5554493000, ext. 4153, email: rmcampos@,colmex.mx.

- World Bank.1818 H Street NW, Washington DC, 20433. Phone: +1-202-477-1234. Email: lflopezcalva@,worldbank.org.

- Tulane University, Department of Economics, 204 Tilton Hall, New Orleans LA, 70118, Phone: +1-504-8628347. Email: mlustig@tulane.edu. 


\section{Introduction}

Since 2000, wage inequality in Mexico has declined (Figure 1). Campos et al. (2014) decompose the change observed in wage inequality into changes in returns to human capital (formal education and work experience) and changes in human capital endowments. Their findings suggest that the endowment effect has been unequalizing while the wage structure effect is equalizing and larger. ${ }^{2}$ A decline in the relative wages of skilled workers can occur if one or more of the following situations exists: the wages of the low-skilled grow faster than the wages of the skilled; the wages of the low-skilled increase while the wages of the skilled workers decline; or the wages of the low-skilled workers decline more gradually than the wages of skilled workers. As illustrated in Figures 2 and 3, the average hourly wage of college-educated workers declined during the entire period while the wages of the rest of workers rose from 2000 to 2008. As a result of the global financial crisis, all wages declined from 2009 onwards but those of college-educated workers fell at a faster pace (Figure 3). ${ }^{3}$

\section{Figure 1. Wage Inequality of All Workers}

A. Gini coefficient of hourly wages

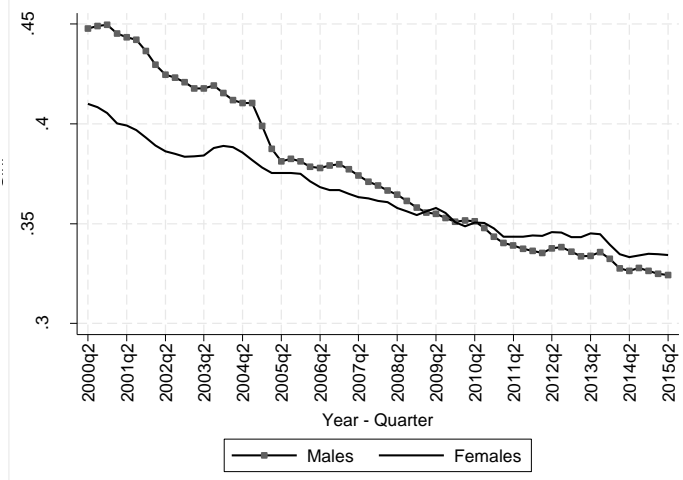

B. Relative supply and relative wages of college-educated workers

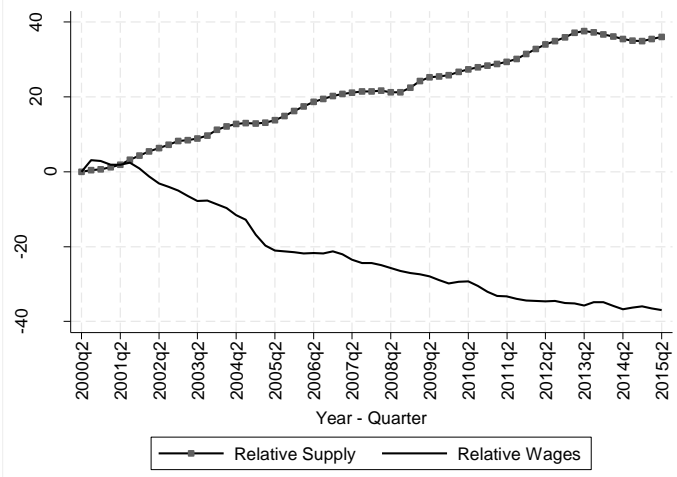

Notes: Authors' calculations using quarterly Labor Force Surveys from 2000 to 2015. Estimations consider all individuals with a positive number of hours worked and valid wages, ages 23-65. Panel B shows the proportional change with respect to 2000:2 of the relative supply of workers (share of individuals with college) and relative wages (log of hourly wage of workers with college education) with respect to rest of workers. This paper aims to establish whether there is evidence in support of a degraded tertiary effect. Sample includes men and women.

\footnotetext{
${ }^{2}$ Even though there was significant educational upgrading and the distribution of the education stock became more equal, these changes were unequalizing because of the so-called "paradox of progress" (see Bourguignon et al. 2005). Depending on the convexity of returns and the point of the education equalization process at which the country finds itself, a reduction in the inequality of educational attainment may lead to a rise in earnings inequality. Indeed, as Gasparini et al. (2011) point out, the 'paradox of progress' has been a pervasive phenomenon in Latin American labor markets in the last couple of decades.

3 This result contrasts with what the literature finds in more advanced countries, which shows an increase in inequality mainly due to wage increases of high-skilled workers (Autor et al. 2008; Goos and Manning, 2007).
} 


\section{Figure 2: Average Monthly Earnings}

A. Less than College

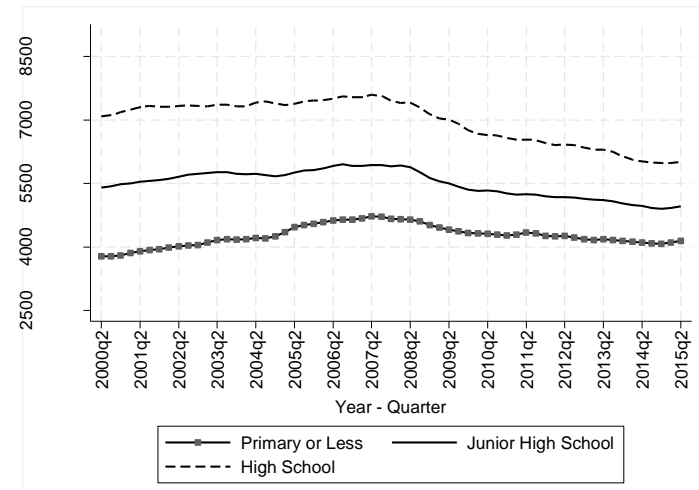

B. College

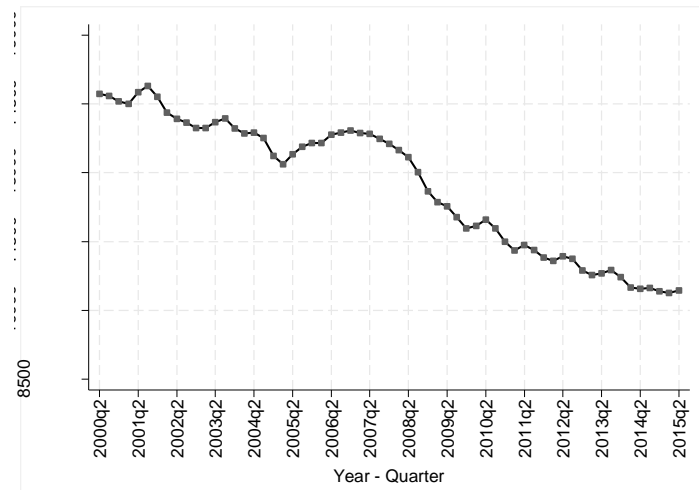

Notes: Authors' calculations using quarterly Labor Force Surveys from 2000 to 2015. Earnings are in constant Mexican Pesos 2014:1. Earnings refer to full-time workers (at least 30 weekly hours of work) with a valid wage. It includes all workers (men and women): salaried, self-employment and owners. Earnings below and above the 1 and 99 percentile (within gender and education group) are dropped. Lines are smoothed by a moving average with a 0.4 weight to the current observation and 0.3 to the previous and post observation.

The average hourly wage for college-educated workers declined at a rate of approximately 2 percent per year between 2001 and 2014. Given that during this period the share of college graduates in the workforce rose from 14 to 18 percent, the decline in relative (and absolute) wages may be a simple matter of supply outpacing demand. An alternative explanation (and not mutually exclusive) could be that the fall in returns to college education is the outcome of a process intrinsic to a particular age group. Younger workers, for example, could be experiencing a decline in their average wage because-as a result of the large expansion of tertiary education institutions since 1995- their tertiary education is not of the same quality on average as that of younger workers in previous cohorts. For example, in the period $1984-$ 1994, university enrollment increased by 1.95 percent per year, while during the 1994-2000 period, it increased by 5.4 percent per year. The skills acquired through tertiary education could have been of lower quality, either because the new post-secondary institutions are of lower quality and/or because the marginal student has lower abilities. We call this the "degraded tertiary effect". Another possibility (again, not mutually exclusive) is that older workers in recent cohorts receive lower wages than their counterparts in previous cohorts because their skills no longer match what the markets demand or because there was a skilled-labor-saving technical change. We call this the "skills-obsolescence effect."

\section{Figure 3: Difference in Log Hourly Wage. Base Period 2008:1.}

\footnotetext{
${ }^{4}$ See Lustig, Lopez-Calva and Ortiz-Juarez (2013) and Camacho and Messina (2014).
} 


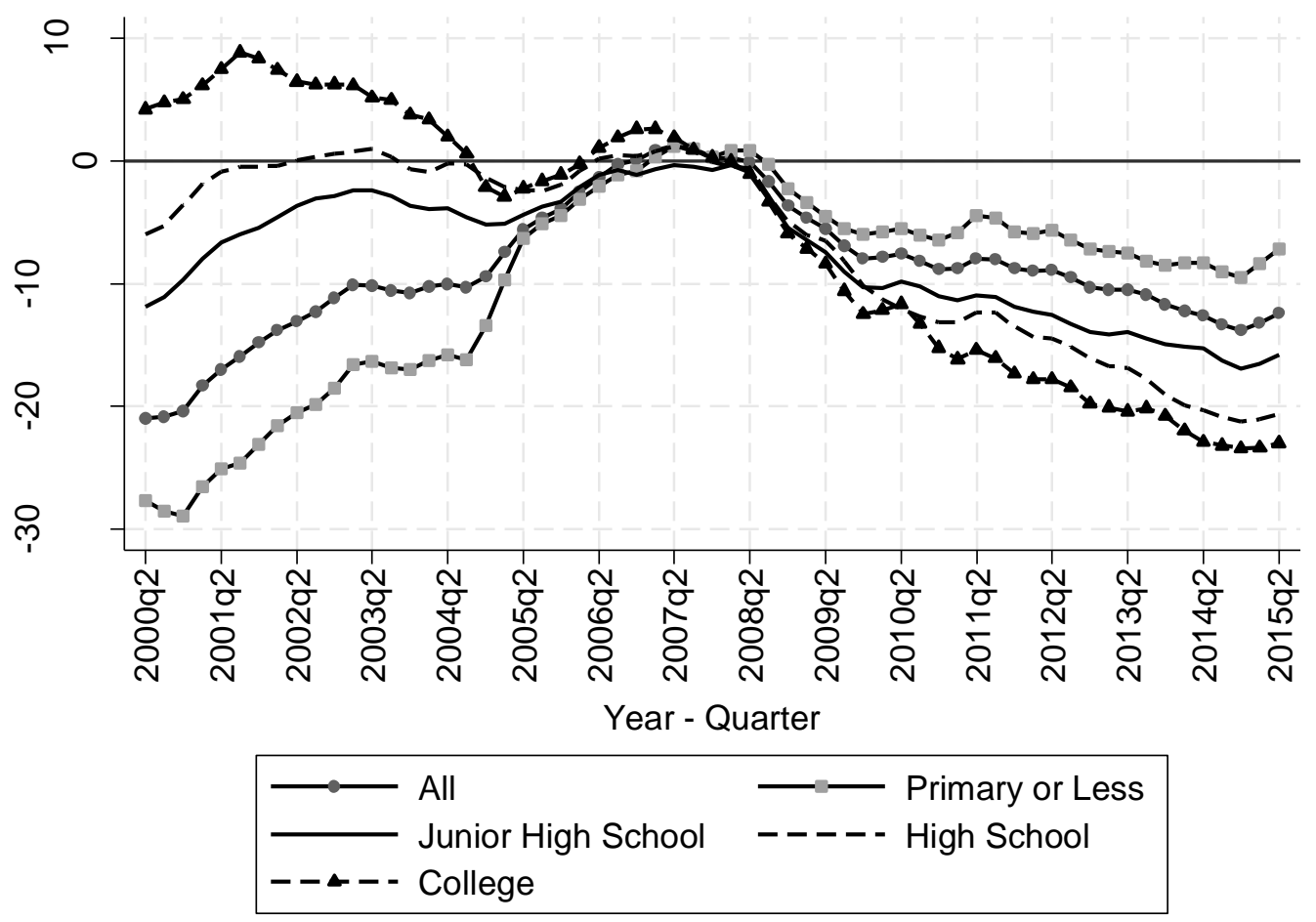

Notes: Authors' calculations using quarterly Labor Force Surveys from 2000 to 2015. Earnings refer to full-time workers (at least 30 weekly hours of work) with a valid wage. It includes all workers (men and women): salaried, self-employment and owners. Earnings below and above the 1 and 99 percentile (within gender and education group) are dropped. Lines are smoothed by a moving average with a a 0.4 weight to the current observation and 0.3 to the previous and post observation.

In this paper, we analyze whether there is evidence of a degraded tertiary education effect, a skills-obsolescence effect, or both. We do this by examining a series of results and assess their consistency with the presence-or absence_of either effect. We posit that if the decline in returns to the college-educated is the result of the deterioration of the quality of new entrants (or a mismatch in demand and supply that affects the younger workers in recent cohorts in particular), this should be reflected in a skewing of the wage distribution towards lower-wage earners among those with tertiary. In order to verify this, we apply the classic Datt-Ravallion decomposition method that disaggregates changes in the proportion of people below the poverty line into growth and redistribution effects (Datt and Ravallion, 1992). We use the average wage of the college-educated in the base year (in lieu of the poverty line). The skewing towards the lower end of the wage distribution exists but it is very small. This result would not be consistent with a degraded tertiary effect or demand-supply mismatch of skills for the younger workers in particular.

The degraded tertiary effect (or a demand-supply mismatch among younger cohorts) should show as a decline in the average hourly wage of younger workers in recent cohorts vis-à-vis workers of the same experience level in older cohorts. However, wages of college-educated workers declined for all ages but they declined faster for the oldest group (51+) and slower for the youngest one (23-30). The observed pattern would be more consistent with the skills- 
obsolescence explanation. In addition, if younger workers had a larger proportion of individuals with lower skills than their preceding cohorts, we would expect that inequality among younger workers would increase more (or decrease less) than for workers of other age groups. However, wage inequality among the younger age group declined. There is no clear difference in the pattern of inequality change among workers of different ages.

We show results for the evolution of wages over time and by cohort (similarly to Juhn et al., 1993). The oldest cohort (1950-1954) shows declines in wages since 2000. The earnings of that cohort have declined close to 40 percent. This is the largest decline in earnings for any cohort. The younger cohorts, 1980-1984 and 1985-1989 do not show a decline in earnings even after the macroeconomic crisis. That is, there is no evidence that workers of newer cohorts are receiving a lower wage when they enter the workforce. In fact, the younger cohorts are the only ones that show an increase in their earnings over time. Finally, we regress the log of the average wage of college-educated workers against age and cohort variables. Estimating the contribution of experience (controlling for education), education (controlling for age) and the interaction of education and experience), suggests that the wage of new entrants has been increasing with each cohort. Again, a result that is not consistent with a presence of increasingly less skilled college educated workers.

The paper is organized as follows. Section 2 introduces the data analyzed in this paper as well as some descriptive statistics. Section 3 presents the analysis of the evidence. Section 4 summarizes the results. Section 5 concludes.

\section{Data}

We use the Labor Force Survey for each quarter starting in the second quarter of 2000. The Mexican labor force surveys are very similar to the Current Population Survey applied in the United States or other labor force surveys around the world. From 2000 to 2004 the survey used is the "Encuesta Nacional de Empleo", and from 2005 to 2014 it is the "Encuesta Nacional de Ocupación $y$ Empleo". Even though the questionnaire is slightly different, most of the key labor questions are the same across surveys: earnings, hours of work, occupation, etc; while the sampling is the same in both. The labor force surveys are representative at the national and state level as well as by metropolitan area. In each quarter, approximately 120,000 households are interviewed. The surveys include socioeconomic and demographic information, but do not include any information on consumption or assets at the household level.

Given that our focus is on college graduate workers, we restrict the sample to individuals aged 23-65 years old (inclusive). For employment patterns, we use the full sample and define 'work' as the positive number of weekly hours of work in the week of reference. For the wage sample, we use full-time earnings defined as earnings of those with more than 30 hours of work in the

\footnotetext{
${ }^{5}$ Both surveys have the same sample design. Although it is not common to employ the two surveys, we use them to provide a complete picture of wages in Mexico since 2000. Other studies that use both surveys are Campos, Hincapie and Rojas (2012) and Calderon (2014).
} 
week of reference. When calculating hourly wages, we divide the monthly earnings by hours of work times 4.33. We drop earnings below and above the 1 st and $99^{\text {th }}$ percentile within education groups from the sample. ${ }^{6}$ To calculate the hourly wage statistics for all workers, we use the expansion factor in the survey times hours of work.

Table 1 shows the descriptive statistics for three years in the data: 2000, 2007 and 2014. Panel A includes the full sample and Panel B includes only the working sample (those with positive hours of work in the week of reference). This distinction is important due to the selection into the labor force mainly by women. There are three large changes in the Mexican population and workforce in the 2000-2014 period. First, there is a substantial increase in the female labor force participation. From 40 percent in 2000, it increased to 48 percent by 2014. This increase has been on hold since the macroeconomic crisis in 2008. Second, the proportion of individuals with a university diploma has increased, while at the same time the proportion of individuals with primary or less has declined substantially. This is satisfied both in the full and the working samples. In the case of women, there is positive selection into the workforce by education. Higher educated women are more likely to enter the labor force than less educated women. Third, average incomes declined substantially after the macroeconomic crisis of 2008. In the results that follow, we explore the role of different explanations on the decline of wages of higher-educated workers. We present our results for both men and women in order to analyze whether there are important changes by gender in labor market outcomes.

Table 1: Descriptive Statistics

\begin{tabular}{lccccccccc}
\hline & & 2000 & & & 2007 & & & 2014 \\
\hline & All & Male & Female & All & Male & Female & All & Male & Female \\
\hline A. Full Sample & & & & & & & & & \\
N & 853,078 & 400,306 & 452,772 & 806,406 & 372,734 & 433,672 & 409,152 & 191,897 & 217,255 \\
Age & 39.1 & 39.2 & 39.1 & 40.3 & 40.4 & 40.1 & 40.9 & 40.9 & 41.0 \\
$\%$ Work & $62 \%$ & $87 \%$ & $40 \%$ & $64 \%$ & $86 \%$ & $46 \%$ & $65 \%$ & $84 \%$ & $48 \%$ \\
$\%$ Married & $75 \%$ & $78 \%$ & $71 \%$ & $73 \%$ & $77 \%$ & $70 \%$ & $71 \%$ & $75 \%$ & $69 \%$ \\
$\%$ Rural & $35 \%$ & $35 \%$ & $34 \%$ & $34 \%$ & $34 \%$ & $34 \%$ & $34 \%$ & $35 \%$ & $34 \%$ \\
$\%$ Primary or less & $54 \%$ & $51 \%$ & $56 \%$ & $45 \%$ & $43 \%$ & $48 \%$ & $36 \%$ & $34 \%$ & $37 \%$ \\
$\%$ Junior High & & & & & & & & & \\
School & $19 \%$ & $21 \%$ & $18 \%$ & $23 \%$ & $25 \%$ & $22 \%$ & $28 \%$ & $29 \%$ & $27 \%$ \\
$\%$ High School & $16 \%$ & $14 \%$ & $17 \%$ & $17 \%$ & $16 \%$ & $18 \%$ & $21 \%$ & $20 \%$ & $21 \%$ \\
$\%$ College & $11 \%$ & $13 \%$ & $9 \%$ & $14 \%$ & $16 \%$ & $12 \%$ & $16 \%$ & $17 \%$ & $15 \%$ \\
B. Working sample & & & & & & & & & \\
N & 536,771 & 345,765 & 191,006 & 530,018 & 320,346 & 209,672 & 268,357 & 160,115 & 108,242 \\
Age & 38.5 & 38.8 & 37.8 & 39.7 & 40.0 & 39.1 & 40.3 & 40.4 & 40.0 \\
$\%$ Full-time work & $85 \%$ & $92 \%$ & $73 \%$ & $82 \%$ & $89 \%$ & $71 \%$ & $82 \%$ & $88 \%$ & $72 \%$ \\
Monthly Earnings & $\$ 6,133$ & $\$ 6,449$ & $\$ 5,330$ & $\$ 6,937$ & $\$ 7,386$ & $\$ 6,003$ & $\$ 5,714$ & $\$ 6,018$ & $\$ 5,116$ \\
Hourly Wage & $\$ 29.3$ & $\$ 30.0$ & $\$ 27.1$ & $\$ 32.5$ & $\$ 33.5$ & $\$ 30.0$ & $\$ 26.8$ & $\$ 27.4$ & $\$ 25.6$
\end{tabular}

${ }^{6}$ This restriction does not affect the trend of the results. Without this restrictions the results are noisier each year. The literature on wage inequality generally follows this convention, see Katz and Autor (1999). 


\begin{tabular}{lccccccccc} 
\% Married & $72 \%$ & $80 \%$ & $57 \%$ & $71 \%$ & $79 \%$ & $58 \%$ & $70 \%$ & $77 \%$ & $58 \%$ \\
$\%$ Rural & $33 \%$ & $36 \%$ & $28 \%$ & $32 \%$ & $34 \%$ & $28 \%$ & $33 \%$ & $36 \%$ & $28 \%$ \\
$\%$ Primary or less & $49 \%$ & $51 \%$ & $46 \%$ & $41 \%$ & $42 \%$ & $38 \%$ & $32 \%$ & $34 \%$ & $30 \%$ \\
$\%$ Junior High & & & & & & & & & \\
$\begin{array}{l}\text { School } \\
\text { \% High School }\end{array}$ & $20 \%$ & $22 \%$ & $18 \%$ & $25 \%$ & $26 \%$ & $22 \%$ & $29 \%$ & $30 \%$ & $26 \%$ \\
$\%$ College & $17 \%$ & $14 \%$ & $22 \%$ & $18 \%$ & $16 \%$ & $22 \%$ & $21 \%$ & $20 \%$ & $23 \%$ \\
\hline
\end{tabular}

Notes: Authors' calculations using quarterly Labor Force Surveys. Each year uses information from all available quarters: 2000 uses quarters 2-4, 2007 uses quarters 1-4, 2014 uses quarters 1-2. Full sample uses all individuals ages 23-65, and working sample uses all individuals with positive hours of work ages 23-65. Monthly earnings and hourly wages are restricted to full-time workers (at least 30 weekly hours of work) and are in constant Mexican Pesos of the first quarter of 2014. Married includes cohabitation. Rural refers to individuals living in localities with less than 15,000 inhabitants. Primary or less refers to individuals with less than 9 years of schooling, Junior High School refers to individuals with at least 9 years but less than 12 years of schooling, High School refers to individuals with at least 12 but less than 16 years of schooling, and College refers to individuals with at least 16 years of schooling.

\section{Results}

Our results can be summarized as follows. The Datt-Ravallion decomposition (Table 2) shows that most of the change in the proportion of workers below the baseline wage is due to a shift in the distribution rather than to a change in its shape. The skewing towards the lower end of the wage distribution exists but it is very small (see Appendix). Based on this result, there does not seem to be evidence consistent with a degraded tertiary effect or demand-supply mismatch of skills for the younger workers in particular. However, this exercise is not sufficient to rule out the presence of labor market dynamics that hurt the younger age group in particular. This is because the Datt-Ravallion decomposition is anonymous in the sense that we are not able to track who is losing relative to other workers. For example, it is possible that changes in the age composition of the workforce are such that although younger workers are increasingly receiving lower wages, their share in the workforce is declining.

Table 2: Datt-Ravallion Decompositions: Log Hourly Wage. Restricted to workers with college.

\begin{tabular}{lcccc}
\hline & 2000 & 2007 & 2014 & \\
\hline A. Males & & & & \\
\% less than mean in 2000 & 0.5088 & 0.5375 & 0.6655 & \\
& & $2000-2007$ & $2007-2014$ & $2000-2014$ \\
Difference & & -0.0286 & -0.1279 & -0.1567 \\
& {$[0.003]$} & {$[0.004]$} & {$[0.004]$} \\
Growth Effect & -0.022 & -0.136 & -0.1486 \\
& {$[0.002]$} & {$[0.003]$} & {$[0.003]$} \\
Redistribution & -0.0065 & 0.008 & -0.008
\end{tabular}


B. Females

$$
[0.002] \quad[0.002] \quad[0.002]
$$

$\%$ less than mean in 2000

$\begin{array}{lll}0.5115 & 0.5049 & 0.6094\end{array}$

Difference

$2000-2007 \quad 2007-2014 \quad 2000-2014$

$0.0066 \quad-0.1045 \quad-0.0979$

Growth Effect

$[0.005] \quad[0.005] \quad[0.005]$

Growth Effect

0.02

$-0.116$

$-0.1073$

[0.003] [0.003]

[0.003]

Redistribution

$-0.014 \quad 0.012$

$-0.009$

[0.003]

[0.003]

[0.003]

Notes: Authors' calculations using quarterly Labor Force Surveys. Each year uses information from all available quarters: 2000 uses quarters 2-4, 2007 uses quarters 1-4, 2014 uses quarters 1-2. Sample restricted to individuals working full-time (at least 30 weekly hours of work) age 23-65 and college education. Log hourly wage in constant Mexican Pesos of the first quarter of 2014. Standard errors in brackets.

What does the evolution of wages and wage inequality by cohort and age group tell us? Figure 4 shows that the wages of college-educated workers declined for all ages but they declined faster for the oldest group (51+) and slower for the youngest one (23-30). This is more evident for males than for females. If the degraded tertiary hypothesis is the only channel to explain changes in wages, then we should expect a decline in wages for younger workers. However, as Figure 4 shows, this did not happen for Mexican workers. This is another piece of evidence against the degraded tertiary hypothesis. ${ }^{7}$ The observed pattern would be more consistent with the skills-obsolescence explanation. It could be that both hypothesis are playing a role in determining wages, but insofar as these results show, the degraded tertiary hypothesis has a secondary role in explaining large wage changes over the period for college educated workers.

Figure 4: Earnings by age group and gender: 2000-2015. Restricted to workers with college.
A. Males
B. Females

\footnotetext{
${ }^{7}$ Figure A3 shows the wage returns by age. The figure illustrates how the wage declines are larger for older workers.
} 

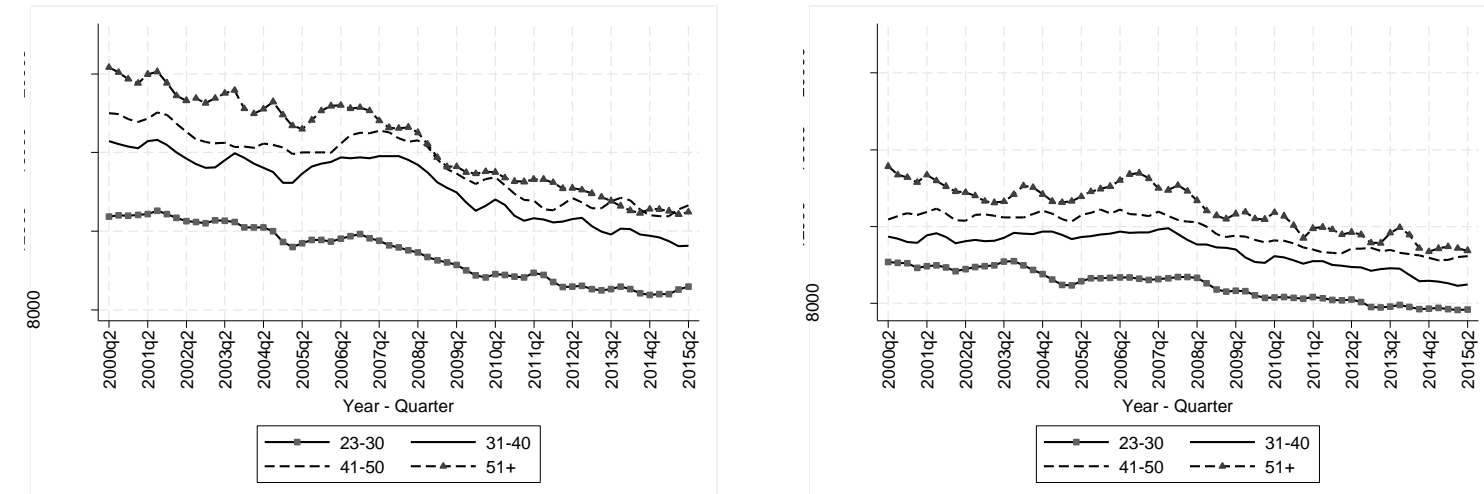

Notes: Authors' calculations using quarterly Labor Force Surveys from 2000 to 2015. Earnings are in constant Mexican Pesos 2014:1. Earnings refer to ful-ltime workers (at least 30 weekly hours of work) with a valid wage. Includes workers with college education: salaried, self-employment and owners. Earnings below and above the 1 and 99 percentile (within gender and education group) are dropped. Lines are smoothed by a moving average with a 0.4 weight to the current observation and 0.3 to the previous and post observation.

As discussed, if a degraded tertiary effect is taking place, we would expect that inequality among younger workers would increase more (or decrease less) than for workers of other age groups. However, as shown in Figure 5, wage inequality among the younger age group declined. There is no clear difference in the pattern of inequality change among workers of different ages (whether males or females). Figure 5 shows a decline in inequality for all workers, including college-educated older workers. Skill-obsolescence (or lower relative demand for older workers in recent cohorts) might imply that high-wage college-educated older workers are earning a lower wage and, hence, inequality for this group would decline. Thus, Figure 5 is more consistent with the skills-obsolescence effect than with the degraded tertiary education hypothesis.

Figure 5: Inequality earnings (Gini) by age group and gender: 2000, 2007 and 2014. Restricted to workers with college.

A. Males

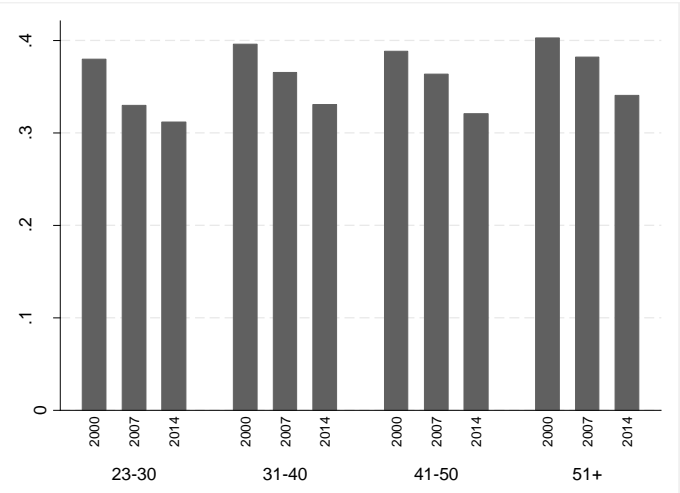

B. Females

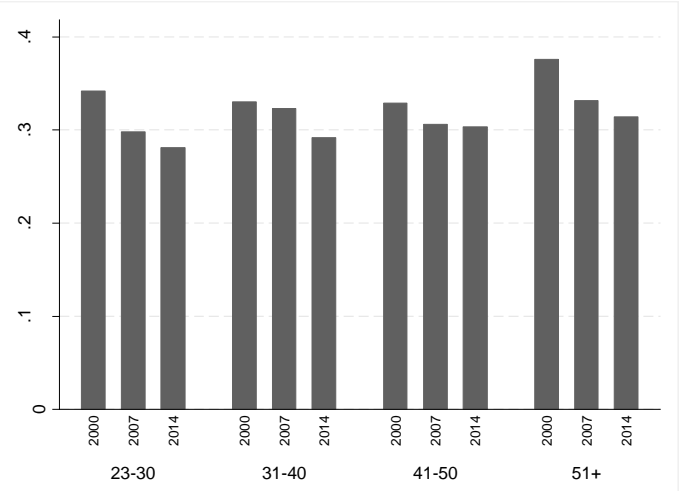

Notes: Authors' calculations using quarterly Labor Force Surveys from 2000 to 2014. Earnings are in constant Mexican Pesos 2014:1. Earnings refer to full-time workers (at least 30 weekly hours of work) with a valid wage. Includes workers with college education: salaried, self-employment and owners. Earnings below and above the 1 
and 99 percentile (within gender and education group) are dropped. Lines are smoothed by a moving average with a 0.4 weight to the current observation and 0.3 to the previous and post observation.

In order to analyze the roles of the degraded tertiary and skill-obsolescence hypotheses, we calculate earnings over time and by cohort. This calculation is important because it depicts how wages have changed over time for the same type of workers. ${ }^{8}$ The degraded tertiary hypothesis should show that wages for recent cohorts declined more pronouncedly (due to increased competition for the same jobs and that the quality of those workers is inferior to that of previous graduates). The skill-obsolescence hypothesis show that older cohorts experienced a more pronounced decline in their wages over time.

Table 3: Mean Log Hourly Wage by Cohort. Males with college education.

\begin{tabular}{cccccccccc}
\hline Cohort & 2000 & 2002 & 2004 & 2006 & 2008 & 2010 & 2012 & 2014 & 2015 \\
\hline $1950-1954$ & 4.29 & 4.28 & 4.19 & 4.25 & 4.16 & 4.14 & 3.99 & 3.93 & 3.85 \\
$1955-1959$ & 4.17 & 4.22 & 4.18 & 4.16 & 4.15 & 4.01 & 4.00 & 3.89 & 3.95 \\
$1960-1964$ & 4.11 & 4.13 & 4.11 & 4.16 & 4.17 & 4.03 & 3.96 & 3.96 & 3.94 \\
$1965-1969$ & 4.12 & 4.14 & 4.08 & 4.13 & 4.09 & 3.97 & 3.95 & 3.93 & 3.97 \\
$1970-1974$ & 3.96 & 4.06 & 4.01 & 4.05 & 4.07 & 3.98 & 3.96 & 3.93 & 3.92 \\
$1975-1979$ & 3.75 & 3.83 & 3.86 & 3.92 & 3.97 & 3.86 & 3.89 & 3.87 & 3.87 \\
$1980-1984$ & & & & 3.74 & 3.75 & 3.72 & 3.77 & 3.77 & 3.74 \\
$1985-1989$ & & & & & & 3.56 & 3.54 & 3.59 & 3.68 \\
\hline
\end{tabular}

Notes: Authors' calculations using quarterly Labor Force Surveys from 2000 to 2015. Earnings are in constant Mexican Pesos 2014:1. Earnings refer to full-time workers (at least 30 weekly hours of work) with a valid wage. Includes workers with college education: salaried, self-employment and owners. Earnings below and above the 1 and 99 percentile (within gender and education group) are dropped. Sample restricted to male workers between 23-65 years old.

Table 3 shows the results for male earnings with college education (the Appendix includes the calculation for women). There are several important aspects to highlight. First, the oldest cohort (1950-1954) shows declines in wages since the beginning of the period. The earnings of that cohort have declined close to 40 percent. This is the largest decline in earnings for any cohort. Second, the cohorts 1955-1959, 1960-1964, and 1965-1969 show stagnant earnings between 2000 and 2008; nevertheless, their earnings all decline after the macroeconomic crisis. This decline is largest for the oldest cohort in this group, 1955-1959. Third, mid-age cohorts, 1970-1974 and 1975-1979, show the largest gains in earnings between the period 2000 and 2008. Their earnings increase between 11 and 22 percent. However, after the macroeconomic crisis, their earnings fall, arriving at the same level as in 2000-2002. Fourth, the younger cohorts, 1980-1984 and 1985-1989 do not show a decline in earnings even after the

\footnotetext{
${ }^{8}$ We cannot follow the same workers as the database employed is not a panel. However, we can use synthetic panels following the same age group over time. If the sampling is random and there is no change in labor force participation (or at least it is random) then wages come from the "same" type of workers.
} 
macroeconomic crisis. However the gains of this cohort are modest, 5 and 2 percent between the first and final year observed. These gains are substantially lower than for older cohorts.

Is there evidence that workers of newer cohorts are receiving a lower wage when they enter the workforce? This phenomenon could be interpreted as evidence consistent with the hypothesis that new entrants are, on average, of increasingly lower quality than new entrants in the preceding cohorts. As Table 3 shows, there is no evidence that this is occurring in the Mexican labor market. In fact, the younger cohorts are the only ones that show an increase in their earnings over time.

However, ideally we would like to compare earnings at the same age across cohorts when they enter the labor force. This is not possible given that the length of the panel is short, and the largest expansion in college enrollment was in the late 1990s. Ideally, we need to compare the cohorts in the early 2000s with the cohorts in the early 1990s. Nevertheless, we can compare wages for three cohorts when they were 23-25 years old. The cohort 1975-1979 had 23 years old (on average) in 2000, the same occurs for the cohort 1980-1984 in 2006 and the cohort 1985-1989 in 2010. The earnings of the cohorts 1975-1979 and 1980-1984 are approximately the same when they both enter the labor force. But the cohort 1985-1989 shows substantially lower earnings at the time of entry into the labor market (close to 20 percent). It is difficult to disentangle the effect of lower college quality due to the macroeconomic crisis in 2008.

In order to explore these issues more deeply, we regress the log of the average wage of collegeeducated workers against age and cohort variables. Estimating the contribution of experience (controlling for education), education (controlling for age) and the interaction of education and experience), suggests the opposite: i.e., the wage of new entrants has been increasing with each cohort. Table 4 shows the results of that regression. The cohort coefficients imply that there is an increasing pattern of earnings up to the 1970-1974 cohort, and then earnings decline for the latter cohorts. The age coefficients imply a regular inverted U-shape for the age-earning profile. The negative coefficient of the interaction between the cohort and age variables is important. This implies that the earnings of younger cohorts start to decline at a younger age over time.

Table 4: Cohort regressions. Log Hourly wage. Restricted to workers with college.

\begin{tabular}{lcc}
\hline & Males & Females \\
\hline Cohort & 0.1624 & 0.3269 \\
& {$[0.083]$} & {$[0.063]$} \\
Cohort $^{2}$ & -0.0224 & -0.0331 \\
& {$[0.006]$} & {$[0.005]$} \\
Age & 0.0625 & 0.0943 \\
& {$[0.016]$} & {$[0.012]$} \\
Age $^{2}$ & -0.0014 & -0.0018 \\
& {$[0.000]$} & {$[0.000]$}
\end{tabular}




\begin{tabular}{lcc} 
Cohort*Age & -0.0082 & -0.0125 \\
& {$[0.002]$} & {$[0.002]$} \\
Constant & 3.5632 & 2.8814 \\
& {$[0.264]$} & {$[0.199]$} \\
& & \\
Observations & 117 & 117 \\
Adj. R-squared & 0.931 & 0.955 \\
\hline
\end{tabular}

Notes: Authors' calculations using quarterly Labor Force Surveys. Cohort starts in 0 and ends in 7 , where 0 is the oldest cohort and 7 is the youngest cohort. Age starts at 0 (Age-23). The constant can be interpreted as the average log hourly wage for the oldest cohort with an average age of 23 .

In order to disentangle the roles of labor demand across age groups, we analyze the pattern of employment by occupation level. We use the two-digit occupation category in the labor force surveys until 2012. ${ }^{9}$ Figures 7 and 8 illustrate that the group that has been hurt the most is the category of Director. Their share in total employment declined (especially among older workers) and their real wages fell the most. This result suggests that labor demand for highly-paid occupations has declined substantially, however this has affected both young and older workers.

Figure 7: Change in Relative Employment by age group. Restricted to workers with college.

A. Age $23-44$

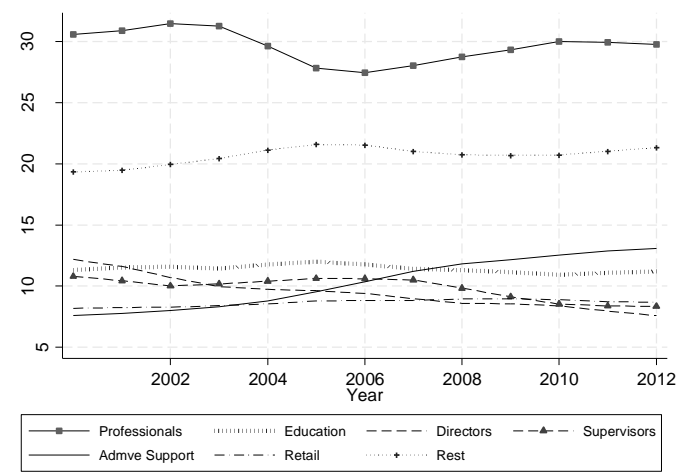

B. Age 45-65

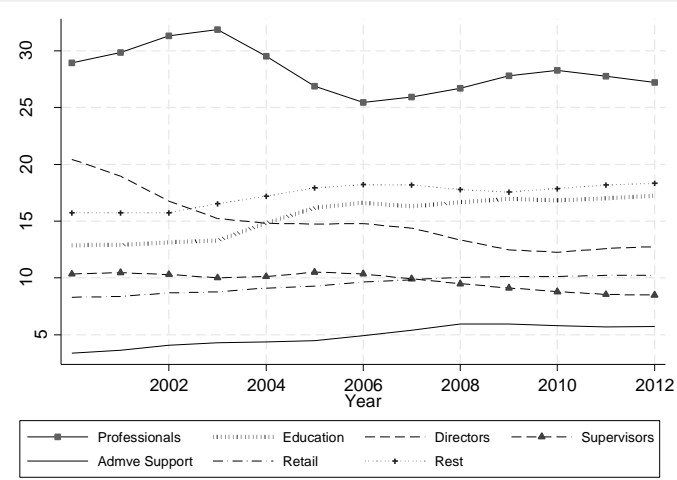

Notes: Authors' calculations using quarterly Labor Force Surveys from 2000 to 2012. Relative employment refers to the share in employment of that occupation out of total employment. Restricted to workers with college education. Lines are smoothed by a moving average with a 0.4 weight to the current observation and 0.3 to the previous and post observation.

\footnotetext{
${ }^{9}$ It is not possible to go up to 2014 because the occupation category changed in 2012. Although the National Statistics and Geography Institute (INEGI) includes a dictionary to match occupation categories between time periods, there are still large discontinuities for some of the occupations in 2012.
} 
Figure 8: Monthly Earnings by age group. Restricted to workers with college.

A. Age $23-44$

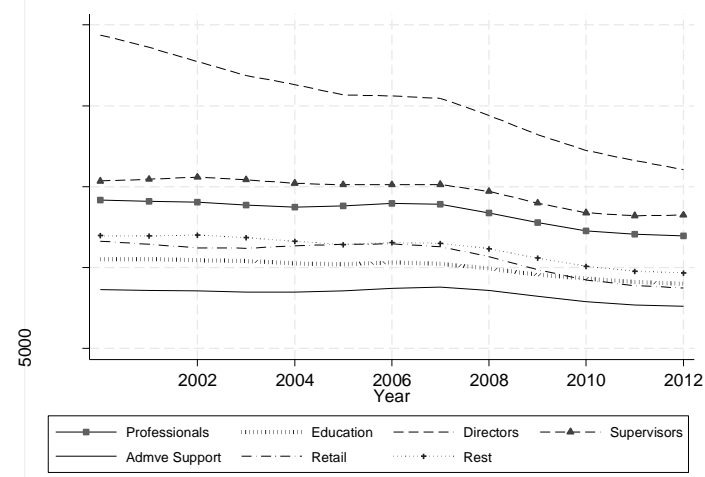

B. Age 45-65

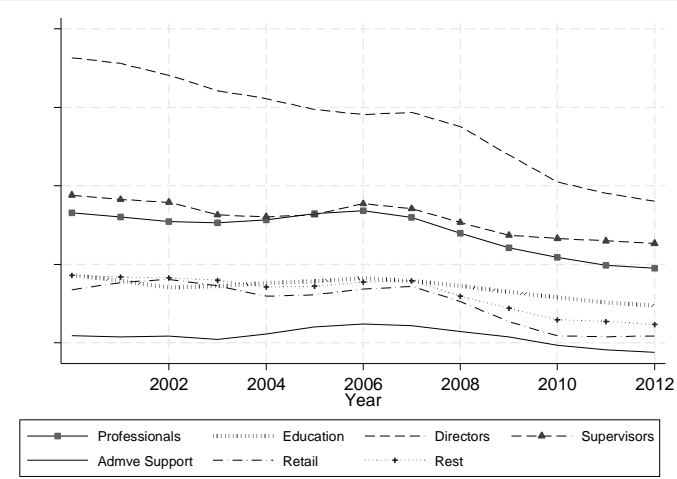

Notes: Authors' calculations using quarterly Labor Force Surveys from 2000 to 2012. Earnings are in constant Mexican Pesos 2014:1. Earnings refer to full-time workers (at least 30 weekly hours of work) with a valid wage. It includes workers with college education: salaried, self-employment and owners. Earnings below and above the 1 and 99 percentile (within gender and education group) are dropped. Lines are smoothed by a moving average with a 0.4 weight to the current observation and 0.3 to the previous and post observation.

\section{Summary of the results}

In sum, there is no evidence supporting the hypothesis that the decline in the wages of collegeeducated workers has been driven by what happened to younger workers. If the degraded tertiary effect or the demand-supply mismatch exists among younger workers, it has been more than offset by other forces. On the other hand, the evidence suggests that there is a process that negatively affects older workers, those of 50 and more in particular. Older workers, for example, do not feature the typical continuously increasing concave wage function; rather, they experience a sharper decline in their wage. These findings are summarized in Table 5. We also observe that the age at which the slope becomes negative occurs at younger ages with each cohort (Table 3 and Figure A7 in the Appendix). This could be evidence of an accelerated skills-obsolescence effect. However, the year at which the wage becomes negative for the college-educated of every cohort coincides with the year in which Mexico entered into recession: 2008.

Table 5: Summary of Evidence

\begin{tabular}{lcll}
\hline Hypothesis & $\begin{array}{c}\text { Shown } \\
\text { in }\end{array}$ & Degraded tertiary & $\begin{array}{c}\text { Obsolescence / Labor } \\
\text { Saving }\end{array}$ \\
\hline Datt-Ravallion & Table 2 & No evidence & Not applicable \\
Evolution of wages & Figure 4 & No evidence & $\begin{array}{l}\text { Some evidence that older } \\
\text { workers' salaries fell more }\end{array}$
\end{tabular}


by age

Wage inequality by Figure 5 No evidence
age

Evolution of wages

by cohort

Cohort regression
Table 3 Some evidence with

the very young cohorts but it overlaps

with year of macroeconomic crisis

Table 4 No evidence. On the contrary, the average entry-point wage has been increasing over time for the younger cohorts rapidly

Evidence consistent with high-wage older workers' wages falling relatively to other older workers' wages

Evidence that the wages of older workers decline

Evidence that the wages of older workers decline in the more recent cohorts and that this accelerates with how recent the cohort is.

\section{Main Findings and Conclusions}

This paper examined whether there is evidence of a degraded tertiary education effect, a skillsobsolescence effect or both in explaining the decline in the relative wages of skilled workers in Mexico, which has been observed since the early 2000s. The fall in returns to college education may be the outcome of a process in a particular age group, for example, lower quality of tertiary education in younger workers - the "degraded tertiary education effect". Another explanation is that older workers in recent cohorts receive lower wages than their counterparts in previous cohorts due to a skill mismatch with the demands of the economy or to a technical change that makes skilled-labor redundant-the "skills-obsolescence effect".

Using data from Mexican labor surveys for the period between 2000 and 2014, we do not find evidence to support the hypothesis that the decline in the relative wages of skilled workers is explained by a degraded tertiary effect or a demand-supply mismatch among younger workers. If these effects have taken place, they have been more than offset by other forces. There is evidence, however, of a process that is taking a negative toll on workers of 50 years of age and older. Rather than a continuously increasing concave wage function, these workers present a sharper decline in their wage.

In addition, there is some support of an accelerated skills-obsolescence effect, which is suggested by the fact that the age at which the slope becomes negative occurs at younger ages with each cohort. Nevertheless, this finding must be interpreted with caution as the year at 
which the wage becomes negative for the college-educated of every cohort (2008) is the same year in which the country entered into recession. 


\section{References}

Autor, David H., Alan Manning and Christopher L. Smith, 2010. "The Contribution of the Minimum Wage to U.S. Wage Inequality over Three Decades: A Reassessment,” NBER Working Papers 16533, National Bureau of Economic Research, Inc.

Autor, D. H., L. F. Katz, \& M.S. Kearney (2008). "Trends in US wage inequality: Revising the revisionists." The Review of Economics and Statistics,90(2), 300-323.

Azevedo, J. P., G. Inchauste, and V. Sanfelice (2013) "Decomposing the Recent Inequality Decline in Latin America", Policy Research Working Paper 6715, The World Bank.

Bourguignon, F., Ferreira, F. H., \& Lustig, N. (2005). A Synthesis of the Results. The Microeconomics of Income Distribution Dynamics in East Asia and Latin America, 357-406.

Campos, R.M., A. Hincapie, and R. I. Rojas (2012). "Family Income Inequality and the Role of Married Females’ Earnings in Mexico: 1988-2010", Latin American Journal of Economics, 49(1): 67-98.

Calderon, G. (2014). “¿Cómo afectan las guarderías en las decisiones laborales de madres? El caso de México", in Los Invisibles-las niñas y niños de 0-6 años, edited by Mexicanos Primero, Chapter 4, 59-78.

Card, D., J. Heining and P. Kline (2012) "Workplace Heterogeneity and the Rise of West German Wage Inequality.” NBER Working Paper 18522.

Datt, G., \& M. Ravallion (1992). Growth and redistribution components of changes in poverty measures: A decomposition with applications to Brazil and India in the 1980s. Journal of Development Economics, 38(2), 275-295.

Gasparini, L., Galiani, S., Cruces, G., \& Acosta, P. A. (2011). Educational upgrading and returns to skills in Latin America: evidence from a supply-demand framework, 1990-2010 (No. 6244). Discussion Paper series, Forschungsinstitut zur Zukunft der Arbeit.

Goos, M., \& Manning, A. (2007). Lousy and lovely jobs: The rising polarization of work in Britain. The Review of Economics and Statistics, 89(1), 118-133.

Jann, B. (2008). “The Blinder-Oaxaca decomposition for linear regression models," Stata Journal, 8(4): 453-479.

Juhn, C, K. M. Murphy and B. Pierce. (1993). "Wage Inequality and the Rise in Returns to Skill," Journal of Political Economy, Vol. 101, No. 3, pp. 410-442.

Katz, L. F., \& D. H. Autor (1999). "Changes in the wage structure and earnings inequality." In Handbook of Labor Economics edited by O. Ashenfelter and D. Card, Volume 3, Chapter 26, 1463-1555.

Lustig, N., Lopez-Calva, L.F., \& Ortiz-Juarez, E. (2014). "Deconstructing the Decline in Inequality in Latin America." In Basu, Kaushik and Joseph Stiglitz "Proceedings of IEA roundtable on Shared Prosperity and Growth," Palgrave-Macmillan (forthcoming in 2015). 


\section{APPENDIX}

\section{Figure A1. Log Hourly Wage Distributions.}

A. Males

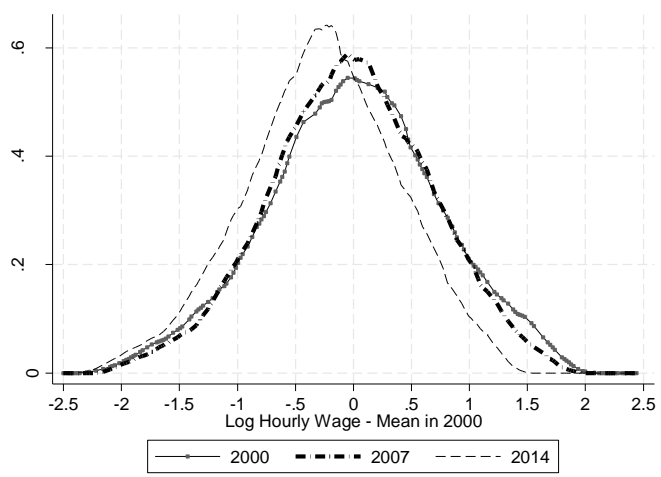

B. Females

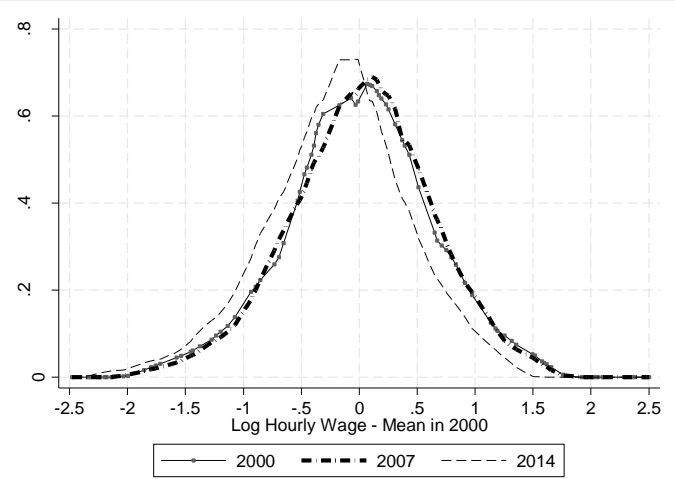

Notes: Authors' calculations using quarterly Labor Force Surveys. Earnings are in constant Mexican Pesos 2014:1. Earnings refer to full-time workers (at least 30 weekly hours of work) with a valid wage. It includes workers with college education: salaried, self-employment and owners. Earnings below and above the 1 and 99 percentile (within gender and education group) are dropped.

Figure A2: Log Hourly Wage

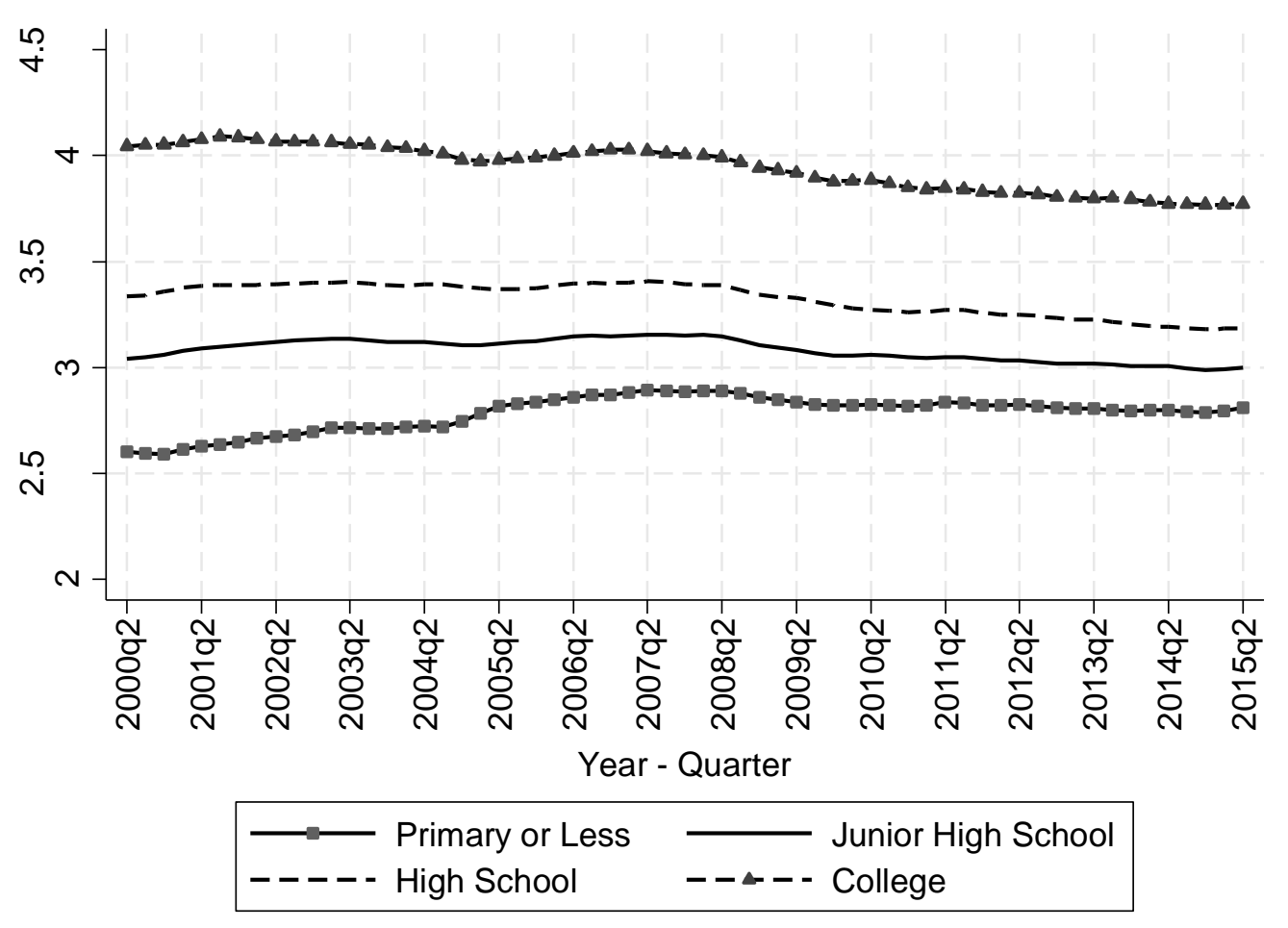

Notes: Authors' calculations using quarterly Labor Force Surveys from 2000 to 2015. Earnings are in constant Mexican Pesos 2014:1. Earnings refer to full-time workers (at least 30 weekly hours of work) with a valid wage. It 
includes workers with college education: salaried, self-employment and owners. Earnings below and above the 1 and 99 percentile (within gender and education group) are dropped. A3: Earnings profile by age and gender: 2000, 2007, 2014.

A. Males

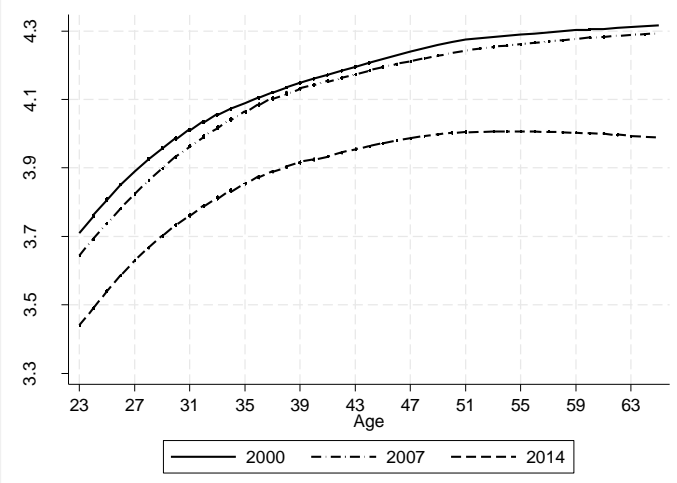

B. Females

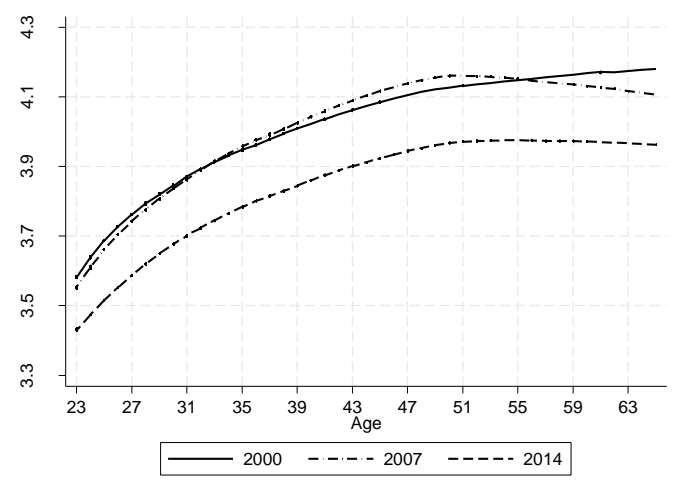

Notes: Authors' calculations using quarterly Labor Force Surveys from 2000 to 2014. Earnings are in constant Mexican Pesos 2014:1. Earnings refer to full-time workers (at least 30 weekly hours of work) with a valid wage. Earnings below and above the 1 and 99 percentile (within gender and education group) are dropped. Lines are smoothed by a moving average with 0.4 weight to the current observation and 0.3 to the previous and post observation.

Figure A4: Proportion of male individuals working. Restricted to workers with college.

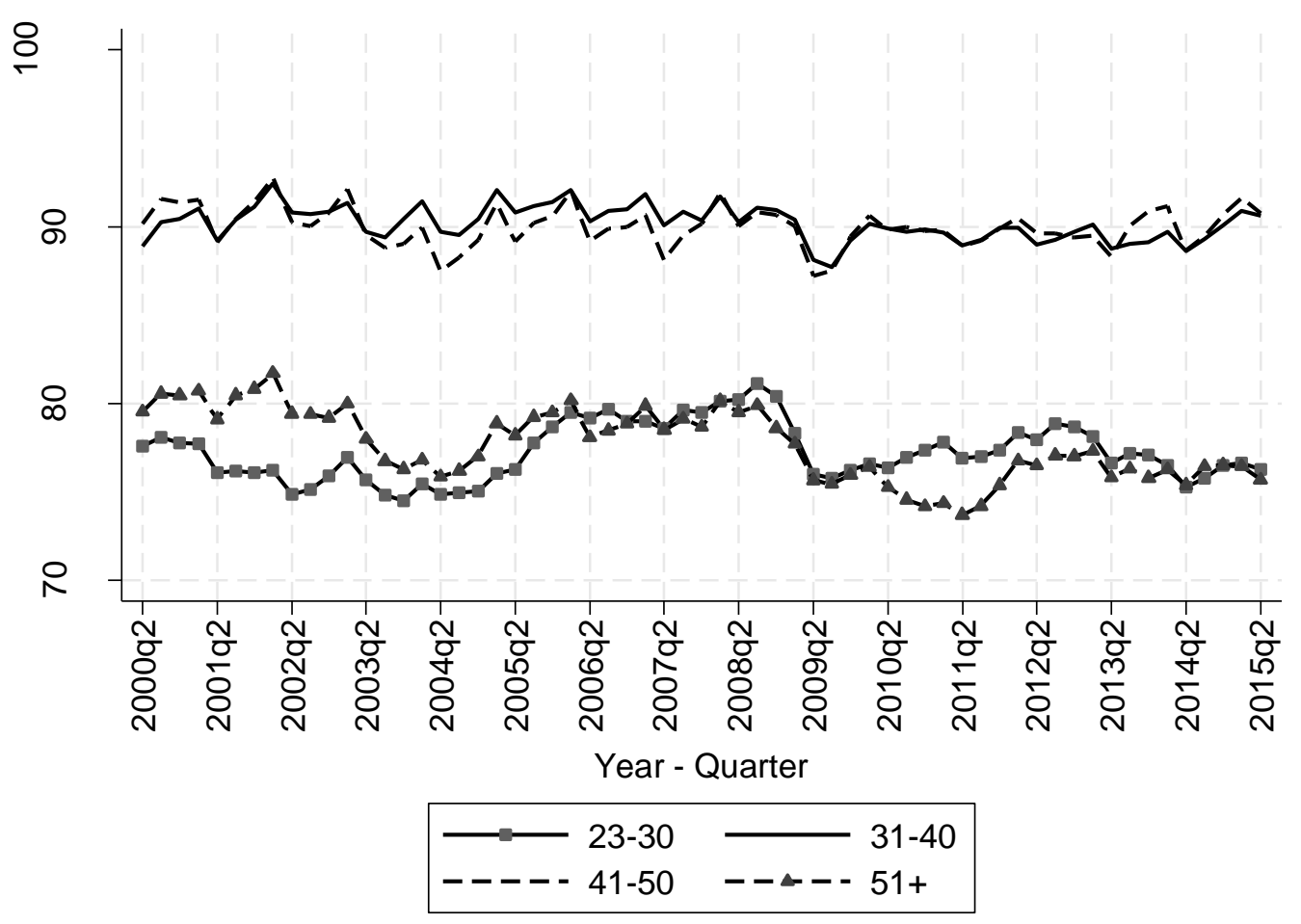

Notes: Authors' calculations using quarterly Labor Force Surveys from 2000 to 2015. Working is defined as positive hours of work in the week of reference. Lines are smoothed by a moving average with a 0.4 weight to the current observation and 0.3 to the previous and post observation. 
Figure A5: Relative Participation in Working (Working in that age group / Total Working) for college-educated workers

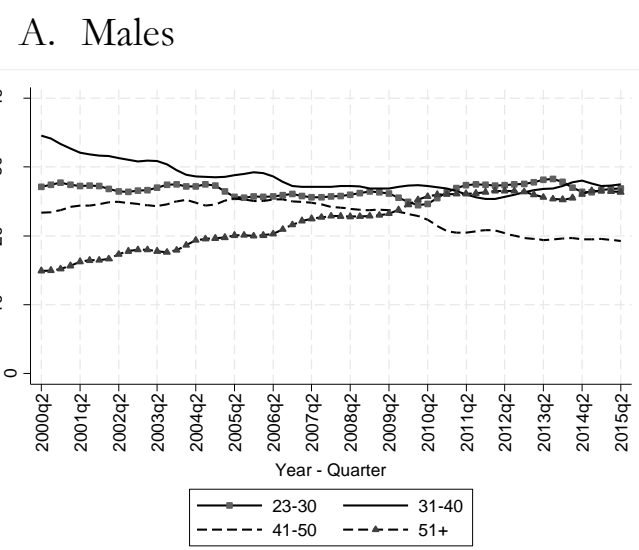

B. Females

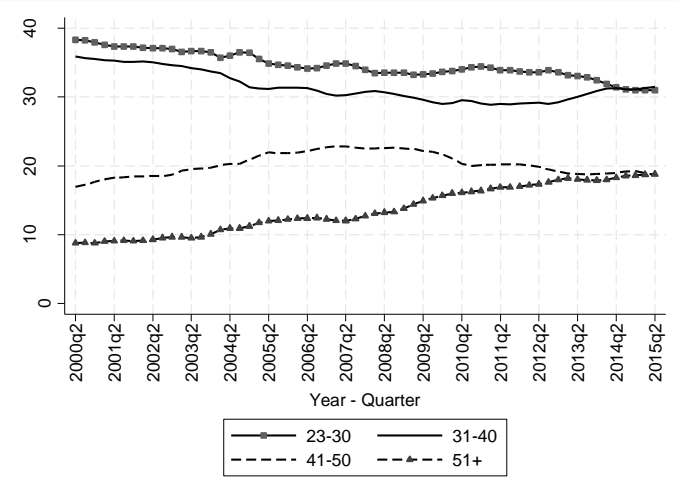

Notes: Authors' calculations using quarterly Labor Force Surveys from 2000 to 2015. Lines are smoothed by a moving average with a 0.4 weight to the current observation and 0.3 to the previous and post observation. In each period total adds to 100 percent.

Figure A6: Unemployment of male individuals by age group for college educated workers

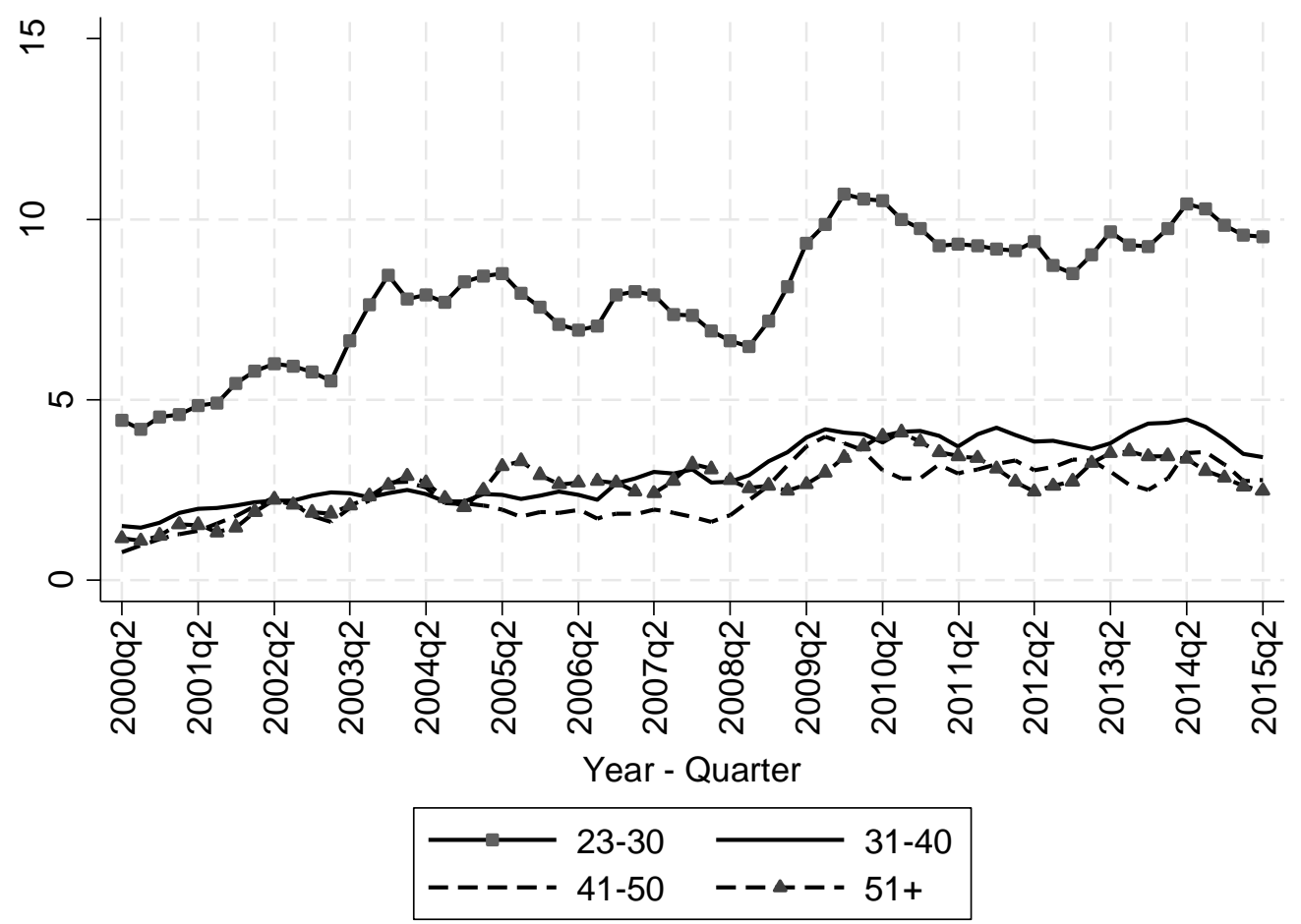

Notes: Authors' calculations using quarterly Labor Force Surveys from 2000 to 2012. Lines are smoothed by a moving average with 0.4 weight to the current observation and 0.3 to the previous and post observation. 
Figure A7: Cohort wage profiles by age. Restricted to workers with college.

A. Males

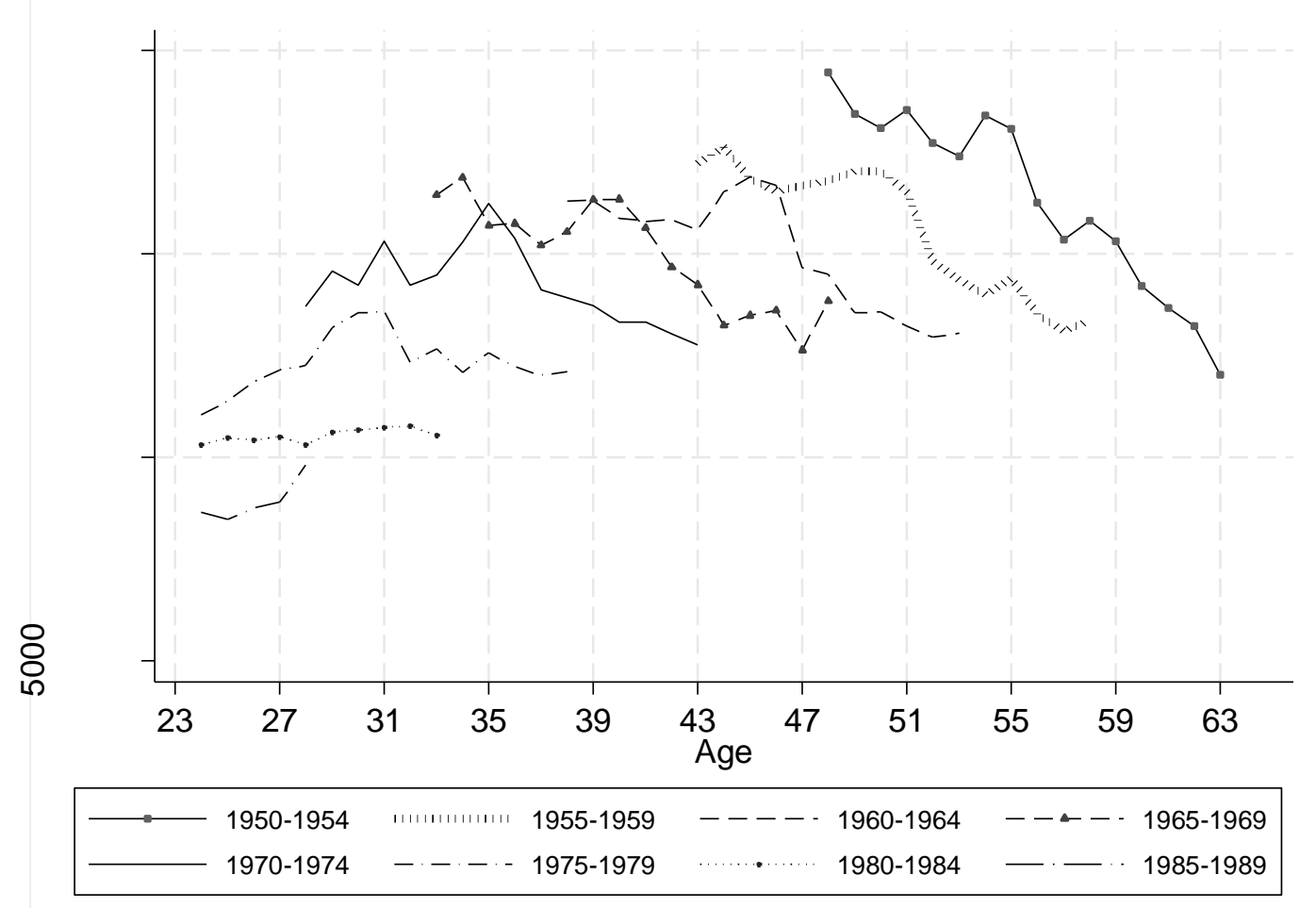

B. Females 


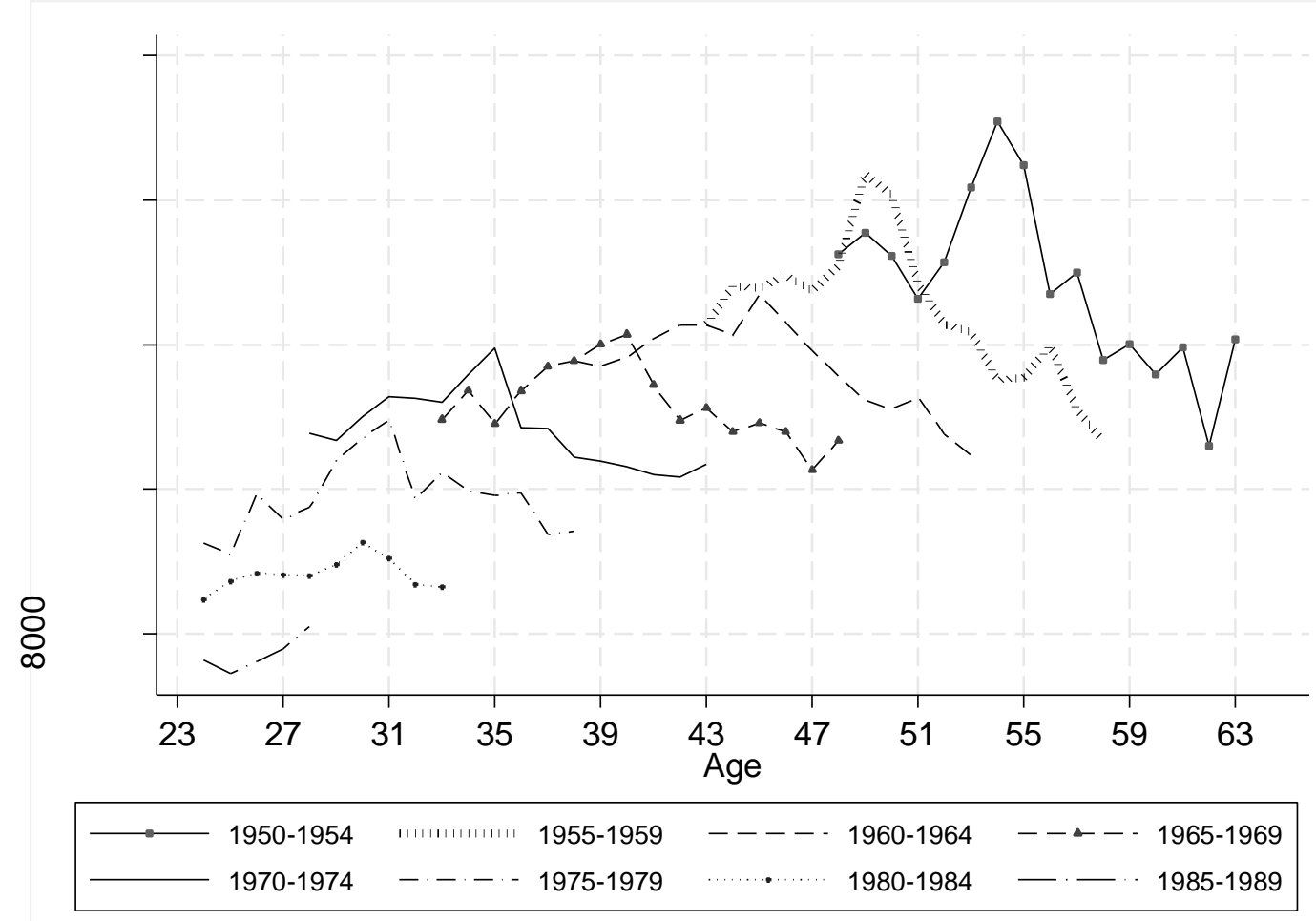

Notes: Constructed by the authors using quarterly Labor Force Surveys from 2000 to 2015. Earnings are in constant Mexican Pesos 2014:1. Earnings refer to full-time workers (at least 30 weekly hours of work) with a valid wage. It includes workers with college education: salaried, self-employment and owners. Earnings below and above the 1 and 99 percentile (within gender and education group) are dropped. Lines are smoothed by a moving average with 0.4 weight to the current observation and 0.3 to the previous and post observation. Age represents the age-midpoint in the respective survey year for each cohort.

Table A1: Mean Wage by cohort. Females.

\begin{tabular}{cccccccccc}
\hline & \multicolumn{7}{c}{ Year } \\
Cohort & 2000 & 2002 & 2004 & 2006 & 2008 & 2010 & 2012 & 2014 & 2015 \\
\hline $1950-1954$ & 4.16 & 4.13 & 4.09 & 4.24 & 4.03 & 3.93 & 3.97 & 3.83 & 3.89 \\
$1955-1959$ & 4.06 & 4.13 & 4.11 & 4.22 & 4.12 & 4.04 & 3.97 & 3.91 & 3.79 \\
$1960-1964$ & 4.02 & 4.01 & 4.08 & 4.07 & 4.09 & 4.02 & 3.92 & 3.92 & 3.89 \\
$1965-1969$ & 3.94 & 3.95 & 4.00 & 4.03 & 3.99 & 3.98 & 3.91 & 3.89 & 3.90 \\
$1970-1974$ & 3.85 & 3.92 & 3.92 & 3.97 & 3.91 & 3.88 & 3.87 & 3.85 & 3.91 \\
$1975-1979$ & 3.68 & 3.74 & 3.75 & 3.83 & 3.91 & 3.83 & 3.81 & 3.79 & 3.78 \\
$1980-1984$ & & & & 3.65 & 3.68 & 3.68 & 3.74 & 3.68 & 3.70 \\
$1985-1989$ & & & & & & 3.53 & 3.52 & 3.56 & 3.61 \\
\hline
\end{tabular}

Notes: Constructed by the authors using quarterly Labor Force Surveys from 2000 to 2015. Earnings are in constant Mexican Pesos 2014:1. Earnings refer to full-time workers (at least 30 weekly hours of work) with a valid wage. It includes workers with college education: salaried, self-employment and owners. Earnings below and above the 1 and 99 percentile (within gender and education group) are dropped. Sample restricted to workers between 23-65 years old. 
Table A2. Oaxaca-Blinder Decomposition. Means and returns: 2000 and 2012.

\begin{tabular}{lllll}
\hline & \multicolumn{2}{c}{ Endowments } & \multicolumn{2}{c}{ Returns } \\
\hline Female & 2000 & 2012 & 2000 & 2012 \\
& 0.304 & 0.394 & -0.114 & -0.066 \\
Married & 0.677 & 0.619 & {$[.011]$} & {$[.012]$} \\
& & & 0.117 & 0.105 \\
Rural & 0.090 & 0.152 & {$[.012]$} & {$[.013]$} \\
& & & -0.315 & -0.202 \\
Age 23-30 & 0.305 & 0.316 & -0.240 & {$[.017]$} \\
& & & {$[.023]$} & {$[.0285$} \\
Age 31-40 & 0.363 & 0.300 & -0.109 & -0.115 \\
& & & {$[.022]$} & {$[.021]$} \\
Age 41-50 & 0.240 & 0.232 & -0.036 & -0.021 \\
& & & {$[.023]$} & {$[.021]$} \\
informal & 0.398 & 0.318 & -0.121 & -0.298 \\
& & & {$[.014]$} & {$[.019]$} \\
selfemp & 0.220 & 0.182 & 0.074 & 0.145 \\
& & & {$[.019]$} & {$[.027]$} \\
\hline
\end{tabular}

Notes: Constructed by the authors using quarterly Labor Force Surveys from 2000 and 2012. Earnings are in constant Mexican Pesos 2014:1. It includes workers with college education: salaried, selfemployment and owners. Sample restricted to full-time and college workers (at least 30 weekly hours of work) with a valid wage. Oaxaca-Blinder decomposition using Stata do file Oaxaca from Jann (2008). Base year is 2000, groups of reference (dummy equals zero): male, age 50-65, formal, salaried, urban, occupations Professionals. Effects on the mean. Occupational dummies are not included due to space limitations, but 19 dummies are included in each regression. 


\section{Figure A8: Oaxaca-Blinder Decomposition. Restricted to workers with college.}

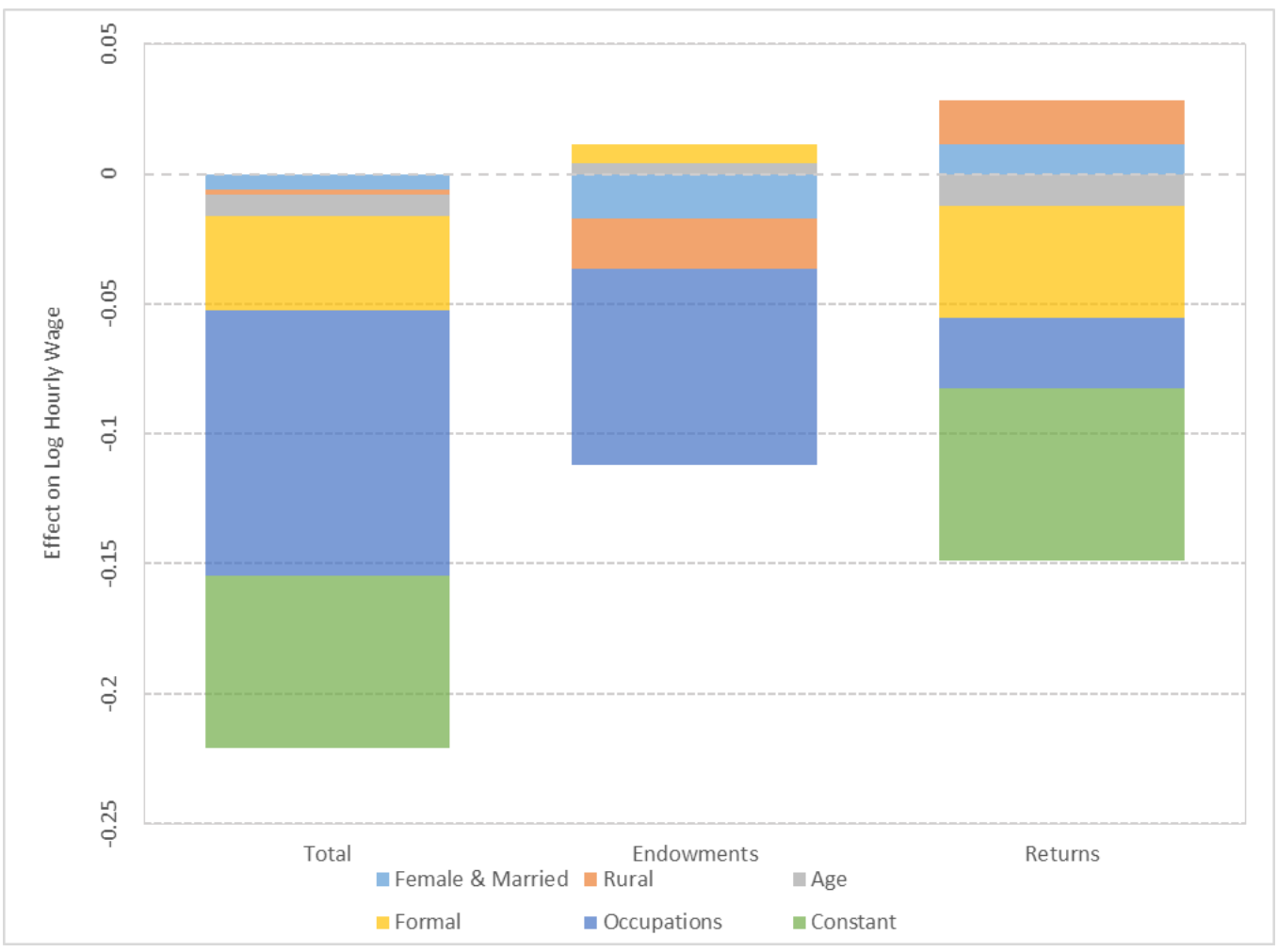

Notes: Constructed by the authors using quarterly Labor Force Surveys from 2000 and 2012. Earnings are in constant Mexican Pesos 2014:1. Earnings refer to full-time workers (at least 30 weekly hours of work) with a valid wage. It includes workers with college education: salaried, self-employment and owners. Earnings below and above the 1 and 99 percentile (within gender and education group) are dropped. Oaxaca-Blinder decomposition using Stata do file Oaxaca from Jann (2008). Base year is 2000, groups of reference (dummy equals zero): male, age 50-65, formal, salaried, urban, occupations Professionals. Effects on the mean. 